\title{
Phosphorus absorption and gene expression levels of related transporters in the small intestine of broilers
}

\author{
Yixin Hu†, Xiudong Liao†, Qian Wen, Lin Lu, Liyang Zhang and Xugang Luo* \\ Mineral Nutrition Research Division, Institute of Animal Science, Chinese Academy of Agricultural Sciences, Beijing 100193, \\ People's Republic of China
}

(Submitted 15 December 2017 - Final revision received 10 March 2018 - Accepted 13 March 2018)

\begin{abstract}
To investigate the $\mathrm{P}$ absorption and gene expression levels of related co-transporters, type IIb sodium-dependent phosphate co-transporter (NaPi-IIb), inorganic phosphate transporter 1 (PiT-1) and inorganic phosphate transporter 2 (PiT-2) in the small intestine of broilers, 450 1-d-old Arbor Acres male broilers were randomly allocated to one of three treatments with ten replicate cages of fifteen birds per cage for each treatment in a completely randomised design. Chickens were fed a diet with no added inorganic P (containing $0.06 \%$ non-phytate P (NPP)) or with either $0 \cdot 21$ or $0.44 \%$ NPP for $21 \mathrm{~d}$. Plasma P concentration in the hepatic portal vein, mRNA and protein expression levels of NaPi-IIb, PiT-1 and PiT-2 were determined at 7, 14 and $21 \mathrm{~d}$ of age. The results showed that the concentration of $\mathrm{P}$ in plasma in the hepatic portal vein increased as dietary NPP increased $(P<0.0001)$. At 14 and $21 \mathrm{~d}$ of age, the increase in dietary NPP inhibited $(P<0.003)$ NaPi-IIb mRNA expression level in the duodenum, as well as PiT-1 mRNA and protein expression levels in the ileum, but promoted NaPi-IIb protein expression level $(P<0.002)$ and PiT-2 mRNA and protein expression levels $(P<0.04)$ in the duodenum. These results suggest that NaPi-IIb, PiT-1 and PiT-2 might be important P transporters in the small intestine of broilers. Higher intestinal $\mathrm{P}$ absorption may be achieved by up-regulating the protein expression levels of NaPi-IIb and PiT- 2 and down-regulating the protein expression of PiT-1.
\end{abstract}

Key words: Phosphorus: Type IIb sodium-dependent phosphate co-transporter: Inorganic phosphate transporter 1: Inorganic phosphate transporter 2: Broilers

$\mathrm{P}$ is an essential mineral for animals, and it plays a critical role in nucleic acid synthesis and metabolism, energy metabolism, membrane integrity, lipid metabolism and bone mineralisation $^{(1)}$. Chicks utilise about $60 \%$ of the dietary $\mathrm{P}$, and the remaining is excreted and may enter the environment leading to eutrophication of fresh water and environmental $\mathrm{P}$ pollution $^{(2-4)}$. Therefore, a better understanding of intestinal $\mathrm{P}$ absorption in chicks will facilitate improving $\mathrm{P}$ utilisation and decreasing $\mathrm{P}$ excretion in the poultry industry. The $\mathrm{P}$ absorption in the small intestine includes transcellular and paracellular pathways $^{(5,6)}$. Paracellular $\mathrm{P}$ transport is dependent on passive diffusion, and active transport occurs through the sodiumdependent $\mathrm{P}$ co-transporters ${ }^{(7)}$. Transcellular permeation is the dominant mechanism for intestinal $\mathrm{P}$ absorption ${ }^{(5,6,8)}$ and involves three types of phosphate co-transporters ${ }^{(6)}$ : type IIb $\mathrm{Na}$-dependent phosphate co-transporter (NaPi-IIb); inorganic phosphate transporter 1 (PiT-1); and inorganic phosphate transporter 2 (PiT-2). The NaPi-IIb is primarily expressed in the duodenum of broilers and is considered to be the most important $\mathrm{P}$ transporter in their small intestine ${ }^{(9-11)}$. The PiT-1 and PiT-2 may play a potential role in intestinal $\mathrm{P}$ absorption in the mouse ${ }^{(6)}$ and rat $^{(12)}$; however, no information is available on the expression levels and physiological roles of PiT-1 and PiT-2 in the small intestine of broilers.

A previous study in broiler chickens has shown that dietary phytase supplementation significantly improved $\mathrm{P}$ absorption but has no effect on intestinal NaPi-IIb mRNA expression ${ }^{(13)}$. This suggests that NaPi-IIb might be not the only $\mathrm{P}$ transporter in the small intestine of broilers. The mechanisms underlying the response of $\mathrm{P}$ transporters to intestinal $\mathrm{P}$ absorption are therefore unclear. Dietary $\mathrm{P}$ deprivation is an important and effective regulator of intestinal $\mathrm{P}$ uptake and gene expression levels of $\mathrm{NaPi}-\mathrm{II} b^{(14,15)}$. We hypothesise that PiT-1 and PiT-2 may be also expressed in the small intestine of broilers and play a role in the regulation of $\mathrm{P}$ absorption. Therefore, the objective of the current study was to test the above hypothesis by investigating the response of NaPi-IIb, PiT-1 and PiT-2 gene expression levels to different dietary non-phytate P (NPP) levels.

\footnotetext{
Abbreviations: C, the control group containing 0.06\% NPP; FI, feed intake; M, the moderate restriction group containing $0 \cdot 21 \%$ NPP; N, the normal group containing $0.44 \%$ NPP; NaPi-IIb, type IIb sodium-dependent phosphate co-transporter; NPP, non-phytate P; PiT-1, inorganic phosphate transporter 1; PiT-2 inorganic phosphate transporter 2 .
}

* Corresponding author: X. Luo, fax +86 10 62810184, email wlysz@263.net

$\dagger$ These authors contributed equally to the present work. 


\section{Methods}

\section{Animals, diets and experimental design}

All experimental procedures were approved by the Animal Management Committee (in charge of animal welfare issue) of the Institute of Animal Sciences, Chinese Academy of Agricultural Sciences (IAS-CAAS), and performed in accordance with the guidelines. Ethical approval on animal survival was given by the animal ethics committee of IAS-CAAS. A total of 450 1-d-old commercial Arbor Acres male broilers were randomly divided into one of three treatment groups with ten replicate cages ( 15 chicks/cage) for each treatment in a completely randomised design. Broilers were housed in electrically heated, thermostatically controlled stainless steel cages (length $100 \mathrm{~cm} \times$ width $50 \mathrm{~cm} \times$ height $45 \mathrm{~cm}$ ) equipped with fibreglass feeders and watering system and were maintained on a 24-h constant light schedule for $21 \mathrm{~d}$. Birds were allowed ad libitum access to the experimental diets and tap water containing no detectable $\mathrm{P}$. The experimental diets were formulated to meet or exceed the requirements of broilers (days 1 to 21) for all nutrients except for NPP (Table 1). One treatment group was fed the basal maize-soyabean meal diet with no inorganic P addition (containing $0.06 \%$ NPP by analysis, control (C)), the second group was fed a diet with the required NPP content according to the recommendation of

Table 1. Ingredients and nutrient levels of diets for broilers from 1 to $21 \mathrm{~d}$ of age $^{\star}$

\begin{tabular}{|c|c|c|c|}
\hline \multirow[b]{2}{*}{ Items } & \multicolumn{3}{|c|}{ Treatments } \\
\hline & C & $\mathrm{M}$ & $\mathrm{N}$ \\
\hline \multicolumn{4}{|l|}{ Ingredients (\%) } \\
\hline Maize & 55.54 & 55.54 & 55.54 \\
\hline Soyabean meal & 36.58 & 36.58 & $36 \cdot 58$ \\
\hline Soyabean oil & 3.82 & $3 \cdot 82$ & 3.82 \\
\hline DL-Methionine $\dagger$ & 0.23 & 0.23 & 0.23 \\
\hline Salt $\dagger$ & 0.30 & 0.30 & 0.30 \\
\hline $\mathrm{CaHPO}_{4} \cdot \mathrm{H}_{2} \mathrm{O}+$ & 0.00 & 0.85 & 2.09 \\
\hline Limestone & $2 \cdot 22$ & 1.72 & 1.02 \\
\hline Sand $\ddagger$ & 0.99 & 0.64 & 0.10 \\
\hline Micronutrients§ & 0.32 & 0.32 & 0.32 \\
\hline \multicolumn{4}{|c|}{ Nutrient composition (\%) } \\
\hline $\mathrm{ME}(\mathrm{MJ} / \mathrm{kg})$ & $12 \cdot 47$ & $12 \cdot 47$ & $12 \cdot 47$ \\
\hline Crude protein $\| \boldsymbol{\Phi}$ & $21 \cdot 7$ & $21 \cdot 8$ & $21 \cdot 7$ \\
\hline Lys & $1 \cdot 12$ & 1.12 & 1.12 \\
\hline Met & 0.55 & 0.55 & 0.55 \\
\hline Met + Cys & 0.91 & 0.91 & 0.91 \\
\hline Call & 1.04 & 1.03 & 1.03 \\
\hline Non-phytate P\| & 0.06 & 0.21 & 0.44 \\
\hline \multicolumn{4}{|c|}{$\begin{array}{l}\text { C, control group; M, moderate restriction group; N, normal group. } \\
\text { * As-fed basis. }\end{array}$} \\
\hline \multirow{2}{*}{\multicolumn{4}{|c|}{$\begin{array}{l}\text { † Feed grade. } \\
\text { ‡ Building sand was washed and then soaked overnight in } 10 \% \text { nitric acid, and } \\
\mathrm{P} \text { content in the washed sand was too low to be detected. Sand was used to adjust } \\
\text { amounts of } \mathrm{CaHPO}_{4} \cdot \mathrm{H}_{2} \mathrm{O} \text { and limestone in each treatment diet. }\end{array}$}} \\
\hline & & & \\
\hline \multirow{6}{*}{\multicolumn{4}{|c|}{ 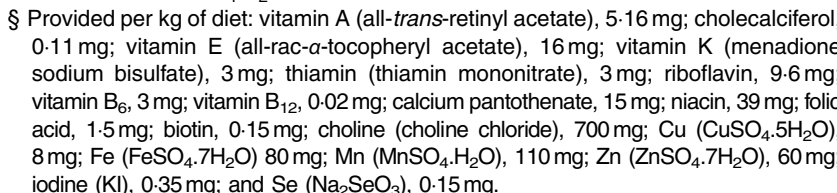 }} \\
\hline & & & \\
\hline & & & \\
\hline & & & \\
\hline & & & \\
\hline & & & \\
\hline \multicolumn{4}{|c|}{ \| Determined values based on triplicate determinations. } \\
\hline
\end{tabular}

National Research Council ${ }^{(16)}(0.44 \%$ NPP by analysis, normal $(\mathrm{N})$ ) and the third group was fed a diet containing half of National Research Council ${ }^{(16)}$-recommended NPP content ( $0.21 \%$ NPP by analysis, moderate restriction (M)). All diets were fed in mash form, and the inorganic $\mathrm{P}$ in the feed was supplemented with $\mathrm{CaHPO}_{4} \cdot \mathrm{H}_{2} \mathrm{O}$. To eliminate the effect of dietary $\mathrm{Ca}$ on intestinal $\mathrm{P}$ absorption, all diets contained the same amount of $\mathrm{Ca}(1 \%)$ by adjusting the supplementation of fine sand and limestone ${ }^{(17,18)}$. Bird weight and feed intake (FI) were measured and corrected for mortality to determine body weight gain (BWG), FI, feed conversion ratio (FCR) and mortality of each cage.

\section{Sample collections and preparations}

Diet samples from all experimental treatments were ground and passed through a $0.50-\mathrm{mm}$ screen before analyses of crude protein, $\mathrm{Ca}$, total $\mathrm{P}$ and phytate $\mathrm{P}$. At 7, 14 or $21 \mathrm{~d}$ of age, three birds from each cage were selected according to average body weight within the cage after a 12-h fast. Birds were anaesthetised by intravenous injections of sodium pentobarbital $(20 \mathrm{mg} / \mathrm{kg}$ of body weight) through a wing vein. Blood was collected from the hepatic portal vein and plasma was separated for $\mathrm{P}$ determination. The birds were then killed by cervical dislocation and the small intestine was exposed by a longitudinal abdominal incision. The duodenum (about $10 \mathrm{~cm}$ distal to the pylorus), jejunum (about $10 \mathrm{~cm}$ preceding the yolk stalk) and ileum $(10 \mathrm{~cm}$ preceding the ileocaecal valve) were dissected out ${ }^{(19)}$ and mucosa was scraped with an ice-cold microscope slide and immediately frozen in liquid $\mathrm{N}_{2}$. After collection, the blood samples were stored at $-20^{\circ} \mathrm{C}$ before $\mathrm{P}$ determination and the mucosa samples were transferred and stored at $-80^{\circ} \mathrm{C}$ before the assays of NaPi-IIb, PiT- 1 and PiT- 2 mRNA and protein expression levels. The plasma and mucosa samples of the three individual broilers from the same cage were pooled before analyses.

\section{Sample analyses}

Dietary crude protein, calcium, total phosphorous and non-phytate phosphorous and plasma phosphorous. The crude protein in the diets was analysed using the Kjeldahl method $^{(20)}$. Crude protein contents were calculated as N (\%, $\mathrm{w} / \mathrm{w}) \times 6 \cdot 25$. The $\mathrm{Ca}$ concentrations in the diets were determined by inductively coupled plasma spectroscopy (Thermal Jarrell Ash) after wet digestion with $\mathrm{HNO}_{3}$ and $\mathrm{HClO}_{4}^{(17)}$. Total $\mathrm{P}$ concentrations in the diets and tap water were determined colorimetrically using the vanadate-molybdate method ${ }^{(17)}$. Validations of the $\mathrm{Ca}$ and total $\mathrm{P}$ analyses were conducted using bovine liver powder (GBW (E) 080193; National Institute of Standards and Technology) as a standard reference. The phytate $\mathrm{P}$ in the diets was determined using the ferric precipitation method $^{(21)}$. Dietary NPP was calculated as the difference between total $\mathrm{P}$ and phytate $\mathrm{P}$. The inorganic $\mathrm{P}$ concentration in plasma from hepatic portal vein blood was determined as described by Goldenberg \& Fernandez ${ }^{(22)}$.

RNA extraction, reverse transcription and real-time $P C R$. Total RNA in mucosa samples was extracted with Trizol reagent (catalogue no. 15596018; Life Technologies) according to the 
Table 2. Primer sequences for real-time PCR amplification

\begin{tabular}{lllc}
\hline Genes & Accession no. & Primer sequences (5'-3') & Product length (bp) \\
\hline PiT-1 & XM_015297502.1 & F: GCTCGTGGCTTCGTTCTTG & 108 \\
PiT-2 & NM_001305398.1 & R: GGACCATTTGACGCCTTTCT & 153 \\
NaPi-Ilb & F: GCAGCAGATACATCAACTC & 128 \\
B-Actin & RM_204474.1 & F: ATTTCCACTCCACCCTC & 152 \\
GAPDH & NM_205518.1 & R: TTATCTTTGGCACCCTCCTG & 128 \\
& NM_204305.1 & F: GAGAATTGTGCGTGACATCA & \\
\hline
\end{tabular}

PiT-1, inorganic phosphate transporter 1; PiT-2, inorganic phosphate transporter 2; NaPi-Illb, type Ilb sodium-dependent phosphate co-transporter; GAPDH, glyceraldehyde-3-phosphate dehydrogenase; F, forward; R, reverse.

manufacturer's instruction. The RNA concentration was determined by measuring UV light absorbance at $260 \mathrm{~nm}$ with a spectrophotometer (ND-2000; Gene Company Ltd) and the integrity of total RNA was checked using denatured RNA electrophoresis. A total of $1 \mu \mathrm{g}$ of RNA was subjected to reverse transcription using a PrimeScript RT reagent kit with gDNA Eraser (catalogue no. RR047A; Takara Bio Inc.) according to the manufacturer's protocol. Quantitative real-time PCR was conducted in triplicate on an ABI 7900 PCR system using Power SYBR Green Master Mix (catalogue no. 4367659; Life Technologies) according to the manufacturer's instructions. The amplification reaction of PCR was performed as follows: $10 \mathrm{~min}$ at $95^{\circ} \mathrm{C}$ and forty cycles of $94^{\circ} \mathrm{C}$ for $15 \mathrm{~s}$ and $60^{\circ} \mathrm{C}$ for $1 \mathrm{~min}$. The target genes and primers (Invitrogen) are shown in Table 2 . The geometric mean of internal references, $\beta$-actin and glyceraldehyde-3-phosphate debydrogenase (GAPDH), was used to normalise the expression of the targeted genes ${ }^{(23,24)}$. Relative mRNA expression levels of target genes were calculated using the $2^{-\Delta \Delta C_{T}}$ method as previously described ${ }^{(25)}$.

Tissue preparation and Western blotting. Frozen intestinal mucosal samples ( $40 \mathrm{mg}$ ) were homogenised in $0.5 \mathrm{ml}$ of ice-cold Radio Immunoprecipitation Assay lysis buffer (catalogue no. P0013B; Beyotime Institute of Biotechnology) supplemented with a protease inhibitor cocktail (catalogue no. B14001; BioTool). After incubating on ice for $30 \mathrm{~min}$, the homogenate was centrifuged at $10000 \mathrm{~g}$ for $5 \mathrm{~min}$ at $4^{\circ} \mathrm{C}$ to harvest the supernatant. The total protein of supernatant was determined using a BCA Protein Assay kit (catalogue no. 23225; Pierce) before it was added to SDS-PAGE loading buffer (catalogue no. CW0027A; $\mathrm{CWBio})$ and put into boiling water $\left(100^{\circ} \mathrm{C}\right)$ for protein denaturation. The denatured proteins $(20 \mu \mathrm{g})$ were separated by electrophoresis on a $10 \%$ SDS-PAGE gel and transferred onto nitrocellulose membranes (catalogue no. IPVH00010; Merck Millipore). Thereafter, the membranes were blocked in blocking buffer with $5 \%$ skimmed milk at room temperature for $1 \mathrm{~h}$ and then incubated overnight at $4^{\circ} \mathrm{C}$ with the following primary antibodies: NaPi-IIb (catalogue no. sc-160605; Santa Cruz Biotechnology), PiT-1 (catalogue no. sc-98814; Santa Cruz Biotechnology), PiT-2 (catalogue no. bs-8610R; Bioss Biotechnology) and GAPDH (catalogue no. HX1828; Huaxingbio). After four washes for $10 \mathrm{~min}$ each with TRIS-buffered saline with Tween, the membranes were incubated with horseradish peroxidase- conjugated secondary antibodies (1:5000) for $1 \mathrm{~h}$ at room temperature. After four washes for $10 \mathrm{~min}$ each, membranes were visualised and signals were recorded with an Image Quant LAS 4000 scanner (GE Healthcare Life Sciences) by enhanced chemiluminescence using a Super Signal West Pico Trail Kit (catalogue no. 34077; Pierce). Band density was analysed using TotalLab Quant software (Total Lab). Data were presented as the ratio of NaPi-IIb, PiT-1 and PiT-2 band intensity: GAPDH protein $^{(11,24)}$, and the average protein expression of the $\mathrm{C}$ group was used as a calibrator ${ }^{(23)}$.

\section{Statistical analyses}

The sample size calculation was performed using software PASS 13 (NCSS, LLC). In our previous study ${ }^{(17)}$, the means of duodenal NaPi-IIb mRNA expression levels for moderately restricted and normal NPP level treatments were 2.32 and 1.03 with a pooled SD of 0.63 . On the basis of the same effect size, five replicates per treatment are needed to achieve $80 \%$ power using a two-sided two-sample $t$ test at a significance level of $0 \cdot 05$. Our proposed sample size of ten replicates per treatment may provide more power when considering multiple comparisons $^{(26)}$. Data from BWG, FI, FCR, mortality, plasma P concentration and protein expression levels of NaPi-IIb, PiT-1 and PiT-2 were analysed by one-way ANOVA using the GLM of SAS (v. 9.2; SAS Institute Inc.) with dietary NPP as the fixed effect. Data from mRNA expression levels of NaPi-IIb, PiT-1 and PiT-2 were analysed by two-way ANOVA using the GLM of SAS with dietary NPP, intestinal segments and their interaction as the fixed effects. Main effects were not analysed separately if the interaction was significant. Comparisons of NaPi-IIb, PiT-1 and PiT-2 protein distributions in different intestinal segments were not made, because the protein expression assays in different intestinal segments could not be replicated within one plate. Owing to the high mortality of birds in the $\mathrm{C}$ group caused by NPP deprivation, the number of surviving birds were not equal between replicate cages at $21 \mathrm{~d}$ of age, and the replicate cage (containing 3-9 birds) served as the experimental unit to determine the overall growth performance from 1 to $21 \mathrm{~d}$ of age. The replicate cage of three birds used for sample collections served as the experimental unit to determine the remaining indices at 7, 14 and $21 \mathrm{~d}$ of age. Data collected at 7, 14 and $21 \mathrm{~d}$ of age were analysed independently. Data from mortality of 
broilers were transformed using arcsin before statistical analysis. Differences among means were tested by the least significant difference, and statistical significance was set at $P<0.05$.

\section{Results \\ Growth performance from 1 to $21 d$ of age}

Dietary NPP level affected $(P<0 \cdot 0001)$ the BWG and overall FI, the mortality and FCR from 1 to $21 \mathrm{~d}$ of age (Table 3 ). With the increase of dietary NPP, the BWG and FI increased and the FCR decreased. In addition, the mortalities were lower $(P<0.0001)$ in the $\mathrm{M}$ and $\mathrm{N}$ groups than in the $\mathrm{C}$ group, with no difference $(P=0.68)$ between the $\mathrm{M}$ and $\mathrm{N}$ groups.

\section{Inorganic phosphorous concentration in plasma from} hepatic portal vein blood at 7, 14 and $21 d$ of age

Inorganic $\mathrm{P}$ concentrations in plasma from the hepatic portal vein were affected $(P<0.0001)$ by dietary NPP at 7,14 and $21 \mathrm{~d}$ of age (Fig. 1). At 7 and $14 \mathrm{~d}$ of age, the concentration of inorganic $P$ in plasma from the hepatic portal vein increased $(P<0 \cdot 05)$ with an increase in dietary NPP. At $21 \mathrm{~d}$ of age, the plasma $\mathrm{P}$ concentrations were significantly lower $(P<0 \cdot 0001)$ in the $\mathrm{C}$ and $\mathrm{M}$ groups than in the $\mathrm{N}$ group, but there were no significant differences $(P=0 \cdot 60)$ between the $\mathrm{C}$ and $\mathrm{M}$ groups.

Type IIb sodium-dependent phosphate co-transporter, inorganic phosphate transporter 1 and inorganic phosphate transporter 2 mRNA levels in different small intestinal segments of broilers at 7, 14 and $21 d$ of age

The results of NaP-IIb, PiT-1 and PiT-2 RNA levels are listed in Table 4 . At $7 \mathrm{~d}$ of age, NaP-IIb mRNA expression was significantly different among intestinal segments $(P<0 \cdot 0001)$, but was not influenced by dietary NPP $(P=0 \cdot 28)$. The interaction between intestinal segment and dietary NPP was not significant $(P=0.63)$. At $14 \mathrm{~d}$ of age, NaPi-IIb mRNA level was affected by dietary NPP $(P<0 \cdot 0001)$ and intestinal segments $(P<0 \cdot 0001)$, but the interaction between NPP and intestinal segment was not significant $(P=0 \cdot 16)$. The NaP-IIb mRNA level was higher $(P=0 \cdot 01)$ in $\mathrm{C}$ and $\mathrm{M}$ groups than in the $\mathrm{N}$ group, with no difference $(P>0.05)$ between the $\mathrm{C}$ and $\mathrm{M}$ groups. At $21 \mathrm{~d}$ of age, there was a significant interaction between dietary NPP and intestinal segment on the NaP-IIb mRNA level $(P<0 \cdot 0001)$. In the duodenum, the NaP-IIb mRNA level was higher $(P<0.0001)$ in the $C$ group compared with that in the $\mathrm{M}$ and $\mathrm{N}$ groups and higher $(P<0.0001)$ in the $\mathrm{M}$ group compared with that in the $\mathrm{N}$ group. In the jejunum, the NaP-IIb mRNA level was higher $(P=0 \cdot 02)$ in the $\mathrm{C}$ group than in the $\mathrm{N}$ group, but there was no difference between $\mathrm{C}$ and $\mathrm{M}(P=0.32)$ or $\mathrm{N}$ and $\mathrm{M}(P=0.13)$ groups. In the ileum, there was no difference $(P>0.31)$ between $\mathrm{C}, \mathrm{M}$ and $\mathrm{N}$ groups. On days 7 and 14, the highest NaPi-IIb mRNA level was found in the duodenum and the least was found in the ileum $(P<0 \cdot 0001)$.

On day 7 , there was a significant interaction between dietary NPP and intestinal segment on the PiT-1 mRNA level
Table 3. Effect of dietary non-phytate phosphorous (NPP) on body weight gain (BWG), feed intake $(F I)$, feed conversion ratio ( $F: G, F C R)$ and mortality of broilers from 1 to $21 \mathrm{~d}$ of age ${ }^{\star}$

\begin{tabular}{lclcc}
\hline NPP level (\%) & BWG (g/bird) & FI (g/bird) & FCR (g:g) & Mortality (\%) \\
\hline $0.06(\mathrm{C})$ & $244^{\mathrm{a}}$ & $419^{\mathrm{a}}$ & $1.70^{\mathrm{a}}$ & $49.3^{\mathrm{a}}$ \\
$0.21(\mathrm{M})$ & $550^{\mathrm{b}}$ & $830^{\mathrm{b}}$ & $1.51^{\mathrm{b}}$ & $2.67^{\mathrm{b}}$ \\
$0.44(\mathrm{~N})$ & $715^{\mathrm{c}}$ & $979^{\mathrm{c}}$ & $1.37^{\mathrm{c}}$ & $2.00^{\mathrm{b}}$ \\
Pooled SEM & 9.75 & 16.3 & 0.03 & 0.05 \\
$P$ & $<0.0001$ & $<0.0001$ & $<0.0001$ & $<0.0001$ \\
\hline
\end{tabular}

$\mathrm{C}$, control group; $\mathrm{M}$, moderate restriction group; $\mathrm{N}$, normal group.

$a, b, c$ Mean values within the same column with unlike superscript letters were significantly different $(P<0.05)$.

${ }^{\star}$ Each value represents the mean of ten replicates $(n 10)$.

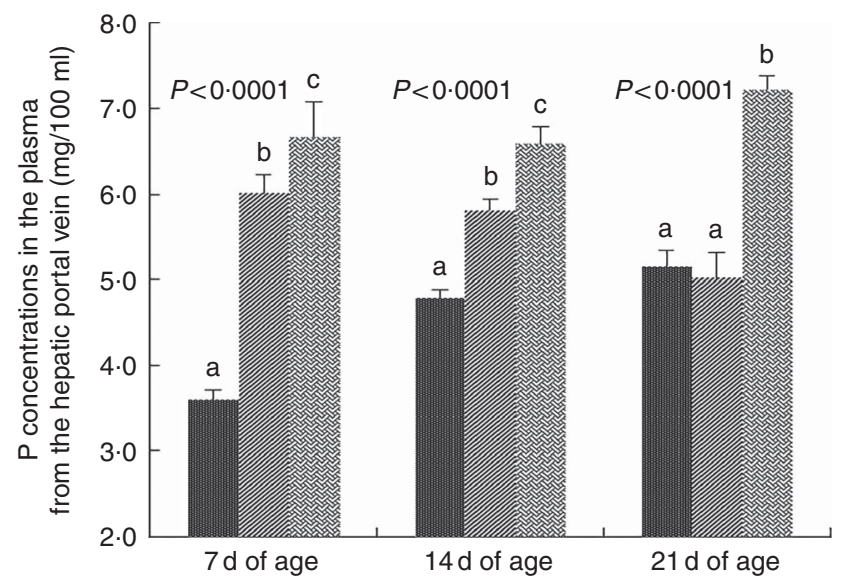

Fig. 1. Effect of dietary non-phytate phosphorous (NPP) on phosphorous contents in plasma from the hepatic portal vein at 7, 14 and $21 \mathrm{~d}$ of age. Values are means ( $n$ 10), with their standard errors represented by vertical bars. $a, b, c$ Mean values with unlike letters between different dietary NPP levels at the

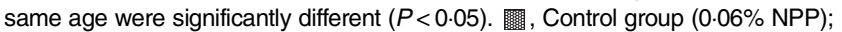
$\mathbb{Z}$, moderate restriction group $(0.21 \% \mathrm{NPP})$; 图, normal group $(0.44 \% \mathrm{NPP})$

$(P=0.04)$. In the jejunum, the PiT-1 mRNA level in $\mathrm{C}$ group was higher $(P<0 \cdot 004)$ than that in $\mathrm{M}$ and $\mathrm{N}$ groups, with no difference $(P=0 \cdot 18)$ between $\mathrm{M}$ and $\mathrm{N}$ groups. In the duodenum or ileum, there was no difference $(P>0.08)$ between the three groups. At $14 \mathrm{~d}$ of age, the PiT-1 mRNA level was affected by dietary NPP $(P=0.02)$ and intestinal segments $(P<0.0001)$ but not the interaction between the two $(P=0 \cdot 38)$. The PiT-1 mRNA levels in the $\mathrm{C}$ and $\mathrm{M}$ groups were higher $(P<0.02)$ than that in the $\mathrm{N}$ group, with no difference $(P=0.97)$ between $\mathrm{C}$ and $M$ groups. At $21 \mathrm{~d}$ of age, the PiT-1 mRNA level was only affected by intestinal segments $(P<0 \cdot 0001)$, and neither dietary NPP $(P=0 \cdot 26)$ nor their interaction $(P=0 \cdot 33)$ had influence on PiT-1 mRNA expression. The highest PiT-1 mRNA level was found in the ileum and the least in the jejunum at 14 and $21 \mathrm{~d}$ of age.

At all times, the PiT-2 mRNA expression was affected by dietary NPP $(P<0.004)$ and intestinal segment $(P<0.007)$ but not by the interaction $(P>0 \cdot 12)$. At all time points, the $\mathrm{C}$ group always had lower $(P<0.04)$ PiT-2 mRNA expression compared with the $\mathrm{M}$ and $\mathrm{N}$ groups, but there were no differences $(P>0.18)$ between $\mathrm{M}$ and $\mathrm{N}$ groups. The highest PiT-2 mRNA was found in the ileum at $7 \mathrm{~d}$ of age, in the duodenum at $14 \mathrm{~d}$ of age and in the jejunum and ileum at $21 \mathrm{~d}$ of age. 
Table 4. Effect of dietary non-phytate phosphorous (NPP) on type Ilb sodium-dependent phosphate co-transporter (NaPi-llb), inorganic phosphate transporter 1 (PiT-1) and inorganic phosphate transporter 2 (PiT-2) mRNA expression levels in the small intestine of broilers at 7, 14 and $21 \mathrm{~d}$ of age (relative quantity $(\mathrm{RQ}))^{\star}$

\begin{tabular}{|c|c|c|c|c|c|c|c|c|c|c|}
\hline \multirow[b]{2}{*}{ Intestinal segments } & \multirow[b]{2}{*}{ NPP level (\%) } & \multicolumn{3}{|c|}{$\mathrm{NaPi-Ilb}$} & \multicolumn{3}{|c|}{ PiT-1 } & \multicolumn{3}{|c|}{ PiT-2 } \\
\hline & & Day 7 & Day 14 & Day 21 & Day 7 & Day 14 & Day 21 & Day 7 & Day 14 & Day 21 \\
\hline \multirow[t]{3}{*}{ Duodenum $†$} & $0.06(C)$ & 1.01 & 1.21 & $1.65^{\mathrm{a}}$ & $1 \cdot 19^{a}$ & $1 \cdot 17$ & 1.29 & 0.82 & 0.84 & 0.73 \\
\hline & $0.21(\mathrm{M})$ & 1.04 & 1.06 & $1 \cdot 16^{b}$ & $1 \cdot 19^{a}$ & $1 \cdot 18$ & 1.32 & 1.08 & 1.11 & 1.54 \\
\hline & $0.44(\mathrm{~N})$ & 1.04 & 0.85 & $0.64^{c}$ & $0.85^{\mathrm{a}}$ & 0.80 & 0.72 & $1 \cdot 17$ & $1 \cdot 18$ & 1.99 \\
\hline \multirow[t]{3}{*}{ Jejunum† } & $0.06(\mathrm{C})$ & 0.77 & 0.26 & $0.56^{c}$ & $3.42^{d}$ & 0.84 & 0.48 & 0.88 & 0.51 & 1.77 \\
\hline & $0.21(\mathrm{M})$ & 0.69 & 0.20 & $0.44^{c, d}$ & $2 \cdot 61^{\mathrm{C}}$ & 0.94 & 0.67 & 1.23 & 0.80 & $2 \cdot 21$ \\
\hline & $0.44(\mathrm{~N})$ & 0.63 & 0.13 & $0.28^{\mathrm{d}, \mathrm{e}}$ & $2 \cdot 89^{C}$ & 0.86 & 0.65 & 1.30 & 0.72 & $2 \cdot 32$ \\
\hline \multirow{3}{*}{ lleum† } & $0.06(\mathrm{C})$ & 0.32 & 0.22 & $0.17^{e, f}$ & $2 \cdot 14^{\mathrm{b}}$ & 1.72 & 1.84 & 1.20 & 0.58 & 1.66 \\
\hline & $0.21(\mathrm{M})$ & 0.32 & 0.18 & $0 \cdot 10^{e, f}$ & $1.83^{b}$ & 1.59 & 1.40 & 1.91 & 0.93 & 1.85 \\
\hline & $0.44(\mathrm{~N})$ & 0.19 & 0.07 & $0.06^{f}$ & $1.87^{b}$ & $1 \cdot 17$ & 1.31 & $2 \cdot 12$ & 0.76 & $2 \cdot 14$ \\
\hline \multirow{4}{*}{$\begin{array}{l}\text { Pooled SEM } \\
\text { NPP levelf }\end{array}$} & & 0.07 & 0.05 & 0.08 & 0.13 & 0.13 & 0.22 & $0 \cdot 11$ & 0.09 & 0.27 \\
\hline & $0.06(C)$ & 0.70 & $0.56^{\mathrm{a}}$ & 0.79 & 2.25 & $1 \cdot 24^{\mathrm{a}}$ & 1.11 & $0.97^{\mathrm{a}}$ & $0.64^{\mathrm{a}}$ & $1.39^{\mathrm{a}}$ \\
\hline & $0.21(\mathrm{M})$ & 0.68 & $0.48^{a}$ & 0.57 & 1.89 & $1 \cdot 24^{\mathrm{a}}$ & 1.52 & $1.41^{\mathrm{b}}$ & $0.95^{\mathrm{b}}$ & $1.87^{\mathrm{b}}$ \\
\hline & $0.44(\mathrm{~N})$ & 0.62 & $0.35^{\mathrm{b}}$ & 0.32 & 1.87 & $0.95^{\mathrm{b}}$ & 0.60 & $1.53^{b}$ & $0.89^{b}$ & $2 \cdot 16^{b}$ \\
\hline Pooled SEM & & 0.04 & 0.03 & 0.05 & 0.08 & 0.07 & 0.13 & 0.07 & 0.05 & 0.15 \\
\hline Duodenum $\ddagger$ & & $1.03^{\mathrm{A}}$ & $1.04^{\mathrm{A}}$ & 1.15 & 1.08 & $1.05^{\mathrm{A}}$ & $1 \cdot 11^{\mathrm{B}}$ & $1.02^{\mathrm{A}}$ & $1.04^{\mathrm{A}}$ & $1.42^{\mathrm{A}}$ \\
\hline Jejunum $\ddagger$ & & $0.70^{\mathrm{B}}$ & $0.20^{\mathrm{B}}$ & 0.43 & 2.97 & $0.88^{\mathrm{A}}$ & $0.60^{\mathrm{A}}$ & $1 \cdot 14^{\mathrm{A}}$ & $0.67^{B}$ & $2 \cdot 11^{\mathrm{B}}$ \\
\hline lleum $\ddagger$ & & $0.27^{C}$ & $0.16^{\mathrm{B}}$ & 0.11 & 1.95 & $1.49^{\mathrm{B}}$ & $1.52^{C}$ & $1.75^{\mathrm{B}}$ & $0.76^{\mathrm{B}}$ & $1.88^{B}$ \\
\hline \multicolumn{10}{|l|}{$P$} & 0.15 \\
\hline NPP & & 0.28 & $<0.0001$ & $<0.0001$ & 0.0005 & 0.02 & 0.26 & $<0.0001$ & $<0.0001$ & 0.004 \\
\hline Segments & & $<0.0001$ & $<0.0001$ & $<0.0001$ & $<0.0001$ & $<0.0001$ & $<0.0001$ & $<0.0001$ & 0.0009 & 0.007 \\
\hline NPP $\times$ segments & & 0.63 & 0.16 & $<0.0001$ & 0.04 & 0.38 & 0.33 & 0.12 & 0.60 & 0.46 \\
\hline
\end{tabular}

C, control group; M, moderate restriction group; N, normal group.

a,b,c,d,e,f Mean values within the same column with different superscript letters were significantly different $(P<0.05)$.

$\mathrm{A}, \mathrm{B}, \mathrm{C}$ Mean values within the same column with different superscript letters were significantly different $(P<0.05)$

* Data are presented in the RQ as the ratio of target mRNA abundance:geometric mean of $\beta$-actin and glyceraldehyde-3-phosphate dehydrogenase mRNA abundances.

† Each value represents the mean of ten replicates $(n 10)$.

$\ddagger$ Each value represents the mean of thirty replicates $(n 30)$.

Type Ilb sodium-dependent phosphate co-transporter, inorganic phosphate transporter 1 and inorganic phosphate transporter 2 protein expression levels in different small intestinal segments of broilers at 7, 14 and $21 d$ of age

The results and representative immunoblots of NaPi-IIb protein expression levels are shown in Fig. 2. The NaPi-IIb protein level was affected by dietary NPP in the duodenum at days 14 and 21 $(P<0.003)$ and in the ileum at day $14(P=0.004)$. NaPi-IIb protein expression of the $\mathrm{C}$ group was lower $(P<0.05)$ than that in the $\mathrm{N}$ and $\mathrm{M}$ groups in the duodenum at 14 and $21 \mathrm{~d}$ of age, with no difference $(P>0.08)$ between $\mathrm{N}$ and $\mathrm{M}$ groups. In the ileum at $14 \mathrm{~d}$ of age, NaPi-IIb protein expression of the $\mathrm{C}$ and $\mathrm{M}$ groups was lower $(P<0.03)$ than that of the $\mathrm{N}$ group, but there was no difference between C and M $(P=0 \cdot 18)$ groups. Dietary NPP did not affect the NaPi-IIb protein expression in the duodenum and jejunum at $7 \mathrm{~d}$ of age $(P>0.64)$ or in the jejunum at $14 \mathrm{~d}$ of age $(P=0.49)$, nor in the jejunum and ileum at $21 \mathrm{~d}$ of age $(P>0.22)$. The NaPi-IIb protein level in the ileum at day 7 was too low to be detected.

The results and representative immunoblots of PiT- 1 protein expression levels are shown in Fig. 3. The protein expression of PiT-1 was affected by dietary NPP in all intestinal segments at all time points $(P<0.003)$, except in the duodenum at $7 \mathrm{~d}$ of age $(P=0.40)$ and in the jejunum at 7 and $21 \mathrm{~d}$ of age $(P>0.19)$. Compared with the $\mathrm{C}$ group, the PiT-1 protein expression was lower in $\mathrm{M}$ and $\mathrm{N}$ groups in the jejunum at day $14(P<0.01)$ and in the ileum at all time points $(P<0.005)$, but there was no difference $(P>0.14)$ between $\mathrm{M}$ and $\mathrm{N}$ groups. In the duodenum at day 14, PiT-1 protein expression of $\mathrm{C}$ and $\mathrm{M}$ groups was higher compared with that in the $\mathrm{N}$ group $(P<0.02)$, but there was no difference between $\mathrm{C}$ and $\mathrm{M}$ groups $(P=0 \cdot 38)$.

The results and representative immunoblots of PiT-2 protein expression levels are given in Fig. 4. Dietary NPP level influenced $(P<0.04)$ PiT-2 protein expression levels in the duodenum at days 14 and 21 , but not $(P>0.06)$ in the duodenum at day 7 or in the jejunum or ileum at any time points. In the duodenum at day 14 , the PiT-2 protein expression in the $\mathrm{N}$ group was higher $(P<0.0001)$ than in the $\mathrm{C}$ and $\mathrm{M}$ groups, with no difference $(P=0.93)$ between the $\mathrm{C}$ and $\mathrm{M}$ groups; however, at day 21 it was higher $(P=0.01)$ in the $\mathrm{N}$ group than in the $\mathrm{C}$ group, with no differences $(P>0 \cdot 11)$ between the $\mathrm{C}$ and $\mathrm{M}$ groups or between the $\mathrm{M}$ and $\mathrm{N}$ groups.

\section{Discussion}

The hypothesis that NaPi-IIb is not the only P transporter in the small intestine and that PiT-1 and PiT-2 are also expressed and may play a role in the regulation of $\mathrm{P}$ absorption in broilers is supported by the results of this experiment. The Na-dependent phosphate transport mechanism plays a major role in $\mathrm{P}$ absorption in the intestine of animals ${ }^{(5,8,27)}$. However, increasing dietary NPP also promoted PiT-2 mRNA and protein expression and inhibited PiT-1 mRNA and protein expression. It may be that PiT-1 was more sensitive to $\mathrm{P}$ accumulation and acting as $\mathrm{P}$ sensor with 
(A)

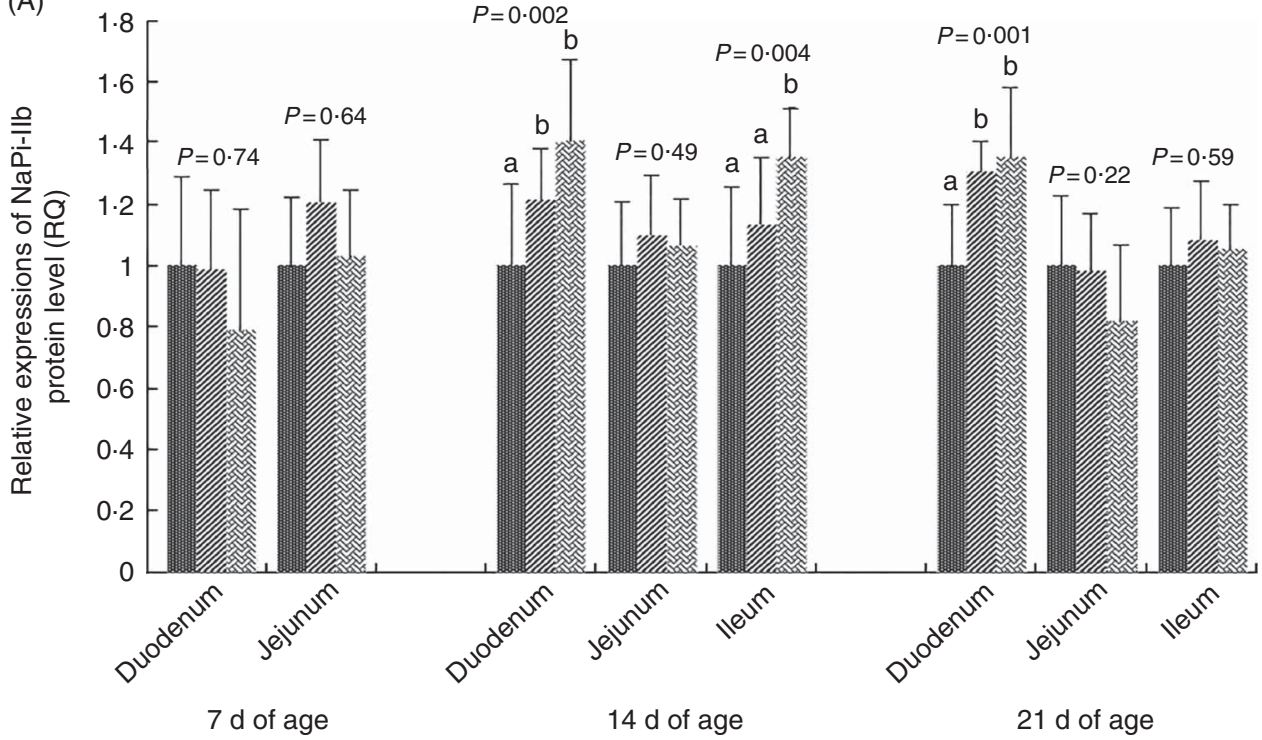

(B)

$\mathrm{NaPi}-\mathrm{Ilb}(70 \mathrm{kDa})$
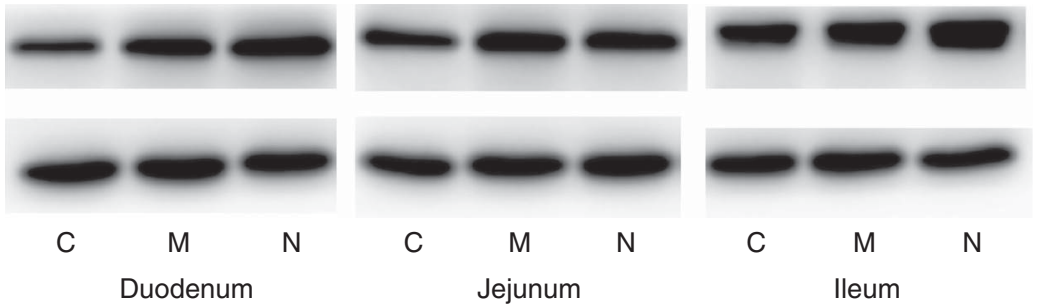

Fig. 2. Effect of dietary non-phytate phosphorous (NPP) on type Ilb sodium-dependent phosphate co-transporter (NaPi-Ilb) protein levels in small intestinal segments of broilers at 7,14 and $21 \mathrm{~d}$ of age $(\mathrm{A})$ and representative immunoblots that were used to detect NaPi-llb protein expressions (B). Data are presented as relative $\mathrm{NaPi}-\mathrm{Ilb}$ band intensity normalised to glyceraldehyde-3-phosphate dehydrogenase (GAPDH) band intensity. Values are means ( $n$ 10), with their standard errors represented by vertical bars. ${ }^{a, b}$ Mean values with unlike letters between different dietary NPP levels in the same intestinal segments at the same age were

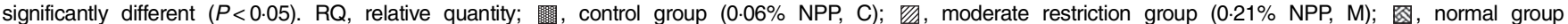
$(0.44 \%$ NPP, N)

down-regulated mRNA and protein expression levels to prevent potentially toxic accumulation of $\mathrm{P}$ in the mucosa. This is speculative, and mechanisms underlying $\mathrm{P}$ sensing need further research. In mammals, PiT-1 and PiT-2 are widely expressed in the kidney, brain, heart, liver, muscle and bone marrow, and their amino acid sequences are approximately $59 \%$ identical ${ }^{(28)}$. Recent studies have also shown that PiT-1 and PiT-2 might have normal cellular functions as phosphate transporters in the rat ${ }^{(29-31)}$, rabbit and hamster ${ }^{(32)}$. Compared with PiT-2, PiT-1 seems to be more sensitive to extracellular $\mathrm{P}$ concentration and serves as an extracellular P-sensing protein in the cell surface of parathyroid gland in response to the circulating $1,25-(\mathrm{OH})_{2}$ vitamin $\mathrm{D}_{3}$ and dietary $\mathrm{P}$ level in rat ${ }^{(31)}$. Studies with the rat fibroblast cells showed that PiT-1 mRNA expression was up-regulated under $\mathrm{P}$ deprivation and down-regulated when the cell was transfected with PiT-2, suggesting that PiT-1 would be more sensitive to cell P status, which regulates its mRNA expression to achieve $\mathrm{P}$ homoeostasis ${ }^{(28)}$.

The NaPi-IIb is the most extensively studied Na-dependent P transporter in terms of function ${ }^{(33)}$, structure ${ }^{(9)}$ and regulation ${ }^{(34-36)}$, and is considered to be responsible for most of the active $\mathrm{P}$ absorption in the small intestine ${ }^{(37)}$. Numerous studies have been carried out to investigate the effect of dietary NPP restriction on $\mathrm{NaPi}-\mathrm{IIb}$ mRNA expression levels in broilers ${ }^{(10,38,39)}$, and results have shown that relatively lower NPP diets promote NaPi-IIb mRNA expression. Therefore, the efficiency of intestinal P absorption is higher when dietary NPP level is limiting ${ }^{(40)}$. These reports are in agreement with the results of the current study but appear inconsistent with the positive relationship between dietary NPP level and $\mathrm{P}$ concentrations in plasma from the hepatic portal vein. Previous studies in goats ${ }^{(41)}$, pigs ${ }^{(40)}$ and mice ${ }^{(42)}$ have shown that NaPi-IIb gene expression was mediated through posttranscriptional processes. In the current study, compared with the $\mathrm{C}$ group, the birds in the $\mathrm{N}$ group had lower NaPi-IIb mRNA levels, but higher plasma $\mathrm{P}$ concentrations and NaPi-IIb protein levels. This indicates that transcriptional processes may regulate $\mathrm{NaPi}$-IIb protein expression in broilers, too. The higher NPP diet promoted intestinal $\mathrm{P}$ absorption and increased plasma $\mathrm{P}$ concentration by increasing $\mathrm{NaPi}-\mathrm{IIb}$ protein expression and possibly reducing its protein turnover to inhibit NaPi-IIb mRNA expression. Studies in rats ${ }^{(12)}$ and chicks ${ }^{(14)}$ demonstrated that both the abundance and activity of NaPi-IIb increased when animals were switched from a low-P diet to a higher-P diet, further indicating that a higher NPP diet promoted intestinal $\mathrm{P}$ absorption by increasing NaPi-IIb protein expression.

The NaPi-IIb mRNA was reported to be exclusively expressed in the small intestine of broilers, with the highest expression in the 
(A)

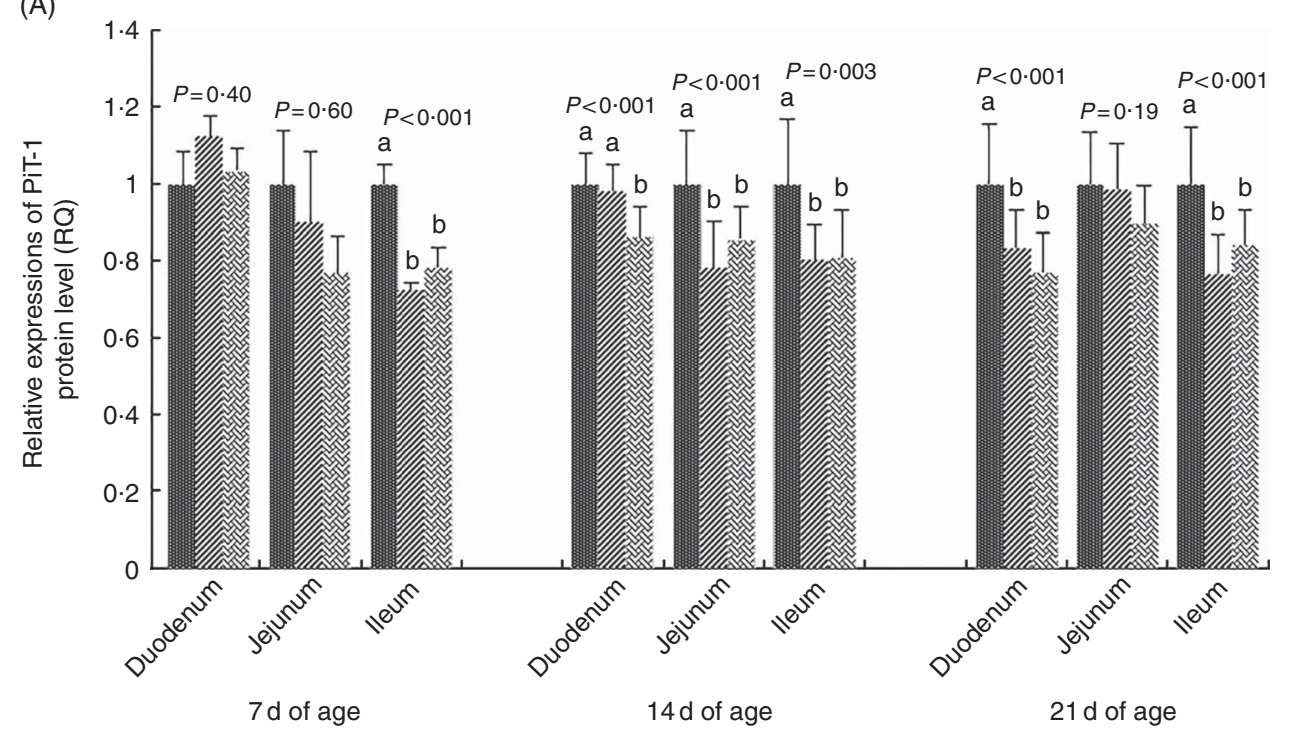

(B)
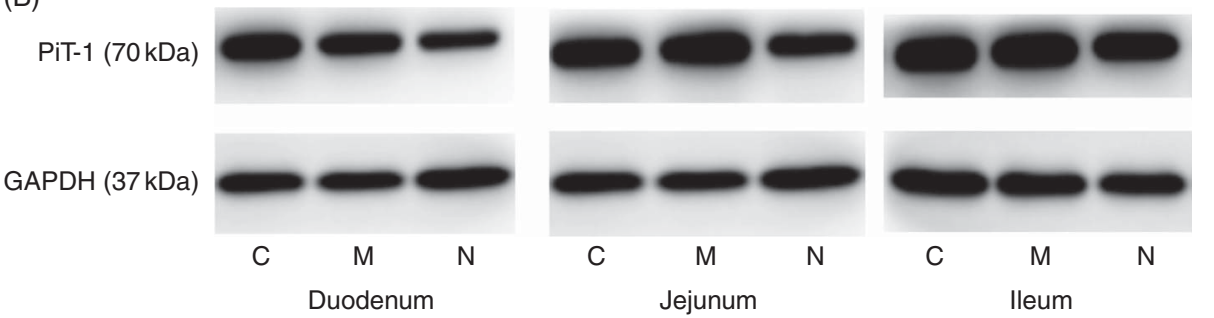

Fig. 3. Effect of dietary non-phytate phosphorous (NPP) on inorganic phosphate transporter 1 (PiT-1) protein levels in small intestinal segments of broilers at 7,14 and $21 \mathrm{~d}$ of age $(\mathrm{A})$ and representative immunoblots that were used to detect PiT-1 protein expressions (B). Data are presented as relative PiT-1 band intensity normalised to glyceraldehyde-3-phosphate dehydrogenase (GAPDH) band intensity. Values are means $(n 10)$, with their standard errors represented by vertical bars. ${ }^{a, b}$ Mean values with unlike letters between different dietary NPP levels in the same intestinal segments at the same age were significantly different $(P<0.05)$. RQ, relative

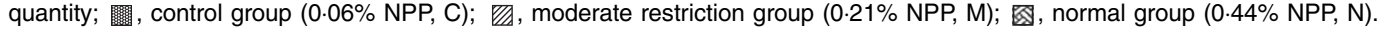

duodenum, followed by the jejunum, and was almost negligible in the ileum ${ }^{(9)}$. A previous study ${ }^{(11)}$ in our laboratory with ligated intestinal loops of broilers has shown that the duodenum is the main site of $\mathrm{P}$ absorption, and $\mathrm{P}$ absorption in the duodenum occurred mainly by a saturated carrier-mediated process and in the ileum or jejunum occurred with a non-saturated diffusion process. These reports are in accordance with our results, and the NaPi-IIb seems to be the main transporter responsible for most of the active $\mathrm{P}$ translocation. However, the relative importance of NaPi-IIb, PiT-1 and PiT-2 in different small intestinal segments is not totally dependent on their gene expression levels, as the affinity of these transporters for $\mathrm{P}$ is highly dependent on luminal $\mathrm{pH}$, which determines the distribution of $\mathrm{H}_{2} \mathrm{PO}_{4}^{1-} / \mathrm{HPO}_{4}^{2-(43)}$. The preferable $\mathrm{P}$ form for NaPi-IIb is $\mathrm{HPO}_{4}^{2-}$, whereas for PiT-1 and PiT-2 it is $\mathrm{H}_{2} \mathrm{PO}_{4}^{1-(43)}$, and thus the different $\mathrm{pH}$ in the duodenum, jejunum and ileum may be another important factor to regulate the amount of $\mathrm{P}$ absorbed through these transporters. Therefore, the relative importance of these transporters in different small intestinal segments may be different, depending on their gene expression levels, $\mathrm{P}$ concentrations, luminal $\mathrm{pH}$ and so on. In addition, the mechanisms underlying the different gene expression levels of PiT-1 and PiT-2 at the three ages remain unknown.

As reported in other studies ${ }^{(17,18)}$, low NPP is associated with a much higher mortality and lower BW and FI. This confirms that
$\mathrm{P}$ is essential for animal health and that the broilers in the $\mathrm{C}$ group were under physiological stress from $\mathrm{P}$ deficiency. Other studies in chicks have shown that serum $\mathrm{P}$ increased proportionately with increasing dietary NPP levels ${ }^{(44,45)}$. These reports agree with our findings and indicate that intestinal $\mathrm{P}$ absorptions are not the same when chicks are fed diets containing different concentrations of NPP. However, the effects of different FI between the three groups on intestinal $\mathrm{P}$ absorption and gene expression levels of NaPi-IIb, PiT-1 and PiT-2 are unclear and need further research.

In summary, our findings from the present study indicate that PiT-1 and PiT-2 are expressed in the small intestine of broilers, and regulate intestinal $\mathrm{P}$ absorption. NaPi-IIb, PiT-1 and PiT-2 may be important transporters responsible for $\mathrm{P}$ absorption in the small intestine, but PiT-2 is likely to be involved in active P translocation, whereas the PiT-1 may be more sensitive to P accumulation and contribute to the regulation of intestinal $\mathrm{P}$ absorption. Higher intestinal $\mathrm{P}$ absorption may be achieved by up-regulating the protein expression levels of NaPi-IIb and PiT-2 and down-regulating the protein expression of PiT-1. The results from the present study also suggest that NaPi-IIb protein expression might be mediated by a post-transcriptional process. These findings provide a novel insight into $\mathrm{P}$ absorption and its mechanisms in the small intestine of broilers, and will contribute to progress in modulating $\mathrm{P}$ absorption and decreasing $\mathrm{P}$ excretions of poultry in the future. 
(A)

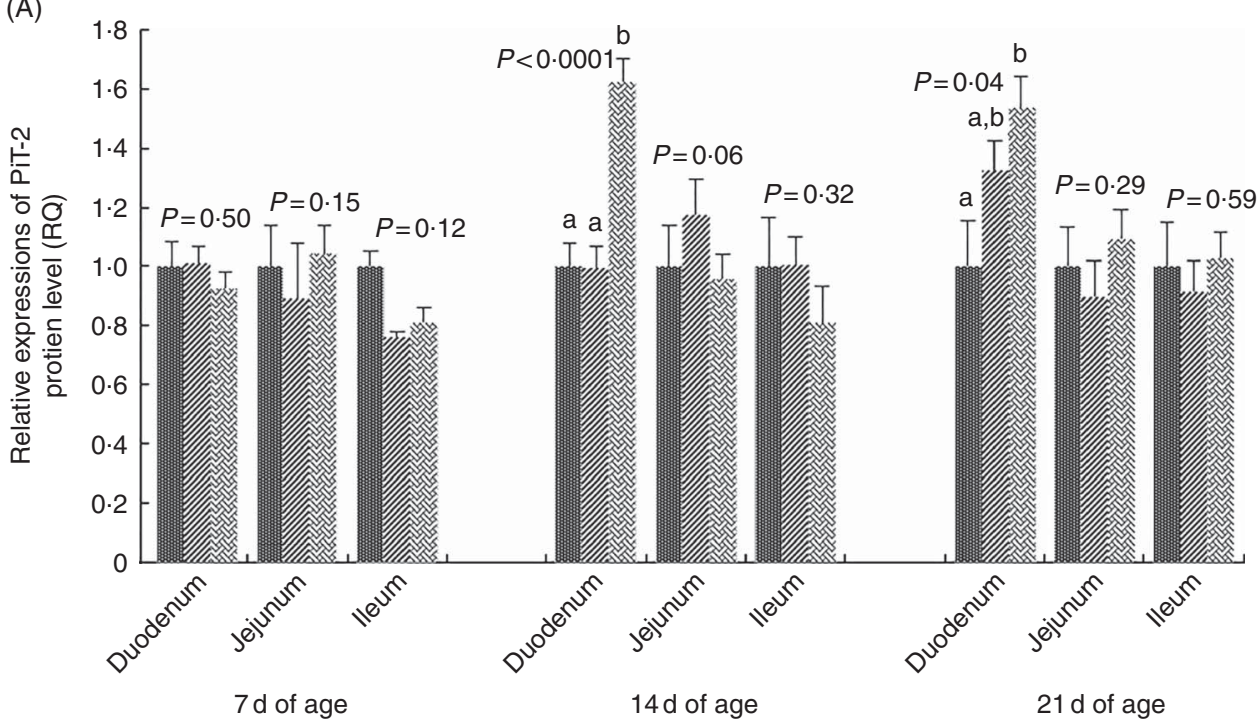

(B)
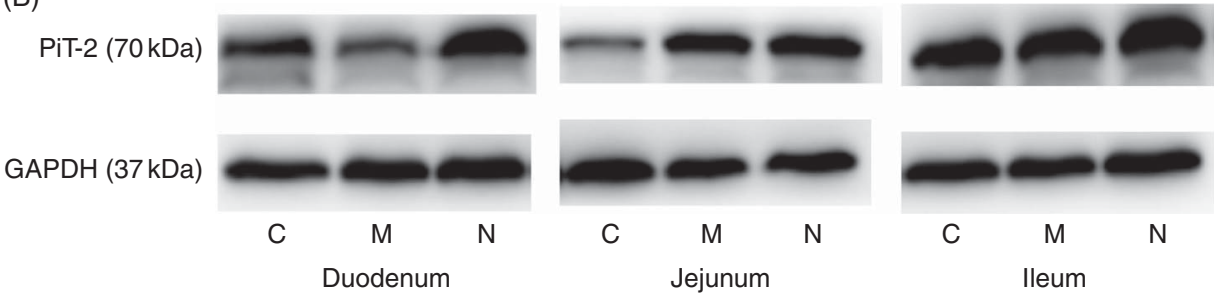

Fig. 4. Effect of dietary non-phytate phosphorous (NPP) on inorganic phosphate transporter 2 (PiT-2) protein levels in small intestinal segments of broilers at 7, 14 and $21 \mathrm{~d}$ of age (A) and representative immunoblots that were used to detect PiT-2 protein expressions (B). Data are presented as relative PiT-2 band intensity normalised to glyceraldehyde-3-phosphate dehydrogenase (GAPDH) band intensity. Values are means $(n)$ ), with their standard errors represented by vertical bars. $a, b$ Mean values with unlike letters between different dietary NPP levels in the same intestinal segments at the same age were significantly

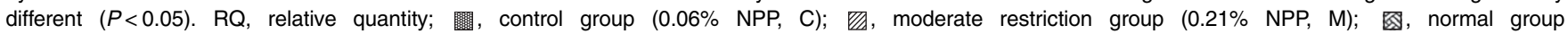
$(0.44 \%$ NPP).

\section{Acknowledgements}

The authors highly appreciate Dr David Masters in the University of Western Australia for assisting with the English editing of this manuscript. In addition, the authors thank Dr Jie Wen for his generous and valuable assistance in the RT-qPCR assays of samples.

This work was supported by the National Natural Science Foundation of China (project no. 31472116; Beijing, P. R. China), the Key Program of the National Natural Science Foundation of China (project no. 31630073; Beijing, P. R. China), the National Key R\&D Program of China (project no. 2017YFD0502200; Beijing, P. R. China), the Agricultural Science and Technology Innovation Program (ASTIP-IAS08; Beijing, P. R. China) and the China Agriculture Research System (project no. CARS-41; Beijing, P. R. China).

The authors' contributions are as follows: X. L. designed the experiment and was responsible for all issues related to this paper. Y. H., Q. W. and L. Z. conducted the research and analysed the samples. Y. H. and X. L. drafted the paper, and L. L. participated in paper writing and editing. All authors have read the paper and agreed with the final content.

The authors declare that there are no conflicts of interest.

\section{References}

1. Berndt T \& Kumar R (2009) Novel mechanisms in the regulation of phosphorus homeostasis. Physiology (Bethesda) 24, 17-25.

2. Liu SB, Li SF, Lu L, et al. (2012) Estimation of standardized phosphorus retention for corn, soybean meal, and cornsoybean meal diet in broilers. Poult Sci 91, 1879-1885.

3. Liu SB, Xie JJ, Lu L, et al. (2013) Estimation of standardized phosphorus retention for inorganic phosphate sources in broilers. J Anim Sci 91, 3766-3771.

4. Liu SB, Li SF, Lu L, et al. (2012) Development of a procedure to determine standardized mineral availabilities in soybean meal for broiler chicks. Biol Trace Elem Res 148, 32-37.

5. Nakagawa N \& Ghishan FK (1993) Transport of phosphate by plasma membranes of the jejunum and kidney of the mouse model of hypophosphatemic vitamin D-resistant rickets. Proc Soc Exp Biol Med 203, 328-335.

6. Bai L, Collins JF \& Ghishan FK (2000) Cloning and characterization of a type III Na-dependent phosphate cotransporter from mouse intestine. Am J Physiol Cell Physiol 279, C1135-C1143.

7. Hilfiker H, Hattenhauer O, Traebert M, et al. (1998) Characterization of a murine type II sodium-phosphate cotransporter expressed in mammalian small intestine. Proc Natl Acad Sci U S A 95, 14564-14569.

8. Eto N, Tomita M \& Hayashi M (2006) NaPi-mediated transcellular permeation is the dominant route in intestinal 
inorganic phosphate absorption in rats. Drug Metab Pharmacokinet 21, 217-221.

9. Yan F, Angel R \& Ashwell CM (2007) Characterization of the chicken small intestine type IIb sodium phosphate cotransporter. Poult Sci 86, 67-76.

10. Li J, Yuan J, Guo Y, et al. (2012) The influence of dietary calcium and phosphorus imbalance on intestinal napi-iib and calbindin mRNA expression and tibia parameters of broilers. Asian-Australas J Anim Sci 25, 552-558.

11. Liu SB, Hu YX, Liao XD, et al. (2016) Kinetics of phosphorus absorption in ligated small intestinal segments of broilers. J Anim Sci 94, 3312-3320.

12. Giral H, Caldas Y, Sutherland E, et al. (2009) Regulation of rat intestinal Na-dependent phosphate transporters by dietary phosphate. Am J Physiol Renal Physiol 297, F1466-F1475.

13. Olukosi OA, Kong C, Fru-Nji F, et al. (2013) Assessment of a bacterial 6-phytase in the diets of broiler chickens. Poult Sci 92, 2101-2108.

14. Fang R, Xiang Z, Cao M, et al. (2012) Different phosphate transport in the duodenum and jejunum of chicken response to dietary phosphate adaptation. Asian-Australas J Anim Sci 25, 1457-1465.

15. Nie W, Yang Y, Yuan J, et al. (2013) Effect of dietary nonphytate phosphorus on laying performance and small intestinal epithelial phosphate transporter expression in Dwarf pink-shell laying hens. J Anim Sci Biotechnol 4, 34.

16. National Research Council (1994) Nutrient Requirements of Poultry, 9th ed. Washington, DC: National Academies Press.

17. Liu SB, Liao XD, Lu L, et al. (2017) Dietary non-phytate phosphorus requirement of broilers fed a conventional corn-soybean meal diet from 1 to $21 \mathrm{~d}$ of age. Poult Sci 96, 151-159.

18. Jiang Y, Lu L, Li SF, et al. (2016) An optimal dietary nonphytate phosphorus level of broilers fed a conventional cornsoybean meal diet from 4 to 6 weeks of age. Animal 10, 1626-1634.

19. Bai SP, Lu L, Wang RL, et al. (2012) Manganese source affects manganese transport and gene expression of divalent metal transporter 1 in the small intestine of broilers. Br J Nutr $\mathbf{1 0 8}$, 267-276.

20. Thiex NJ, Manson H, Anderson S, et al. (2002) Determination of crude protein in animal feed, forage, grain, and oilseeds by using block digestion with a copper catalyst and steam distillation into boric acid: collaborative study. J AOAC Int 85, 309-317.

21. Selle P, Ravindran V, Cadogan D, et al. (1996) The role of microbial phytases in poultry and pig production. Aust Poult Feed Conv 10, 219-224.

22. Goldenberg H \& Fernandez A (1966) Simplified method for the estimation of inorganic phosphorus in body fluids. Clin Chem 12, 871-882.

23. Zhu YW, Lu L, Li WX, et al. (2015) Effect of dietary manganese on antioxidant status and expression levels of heat-shock proteins and factors in tissues of laying broiler breeders under normal and high environmental temperatures. Br J Nutr $\mathbf{1 1 4}$ 1965-1974.

24. Zhang LY, Li XF, Liao XD, et al. (2017) Effect of iron source on iron absorption and gene expression of iron transporters in the ligated duodenal loops of broilers. J Anim Sci 95, 1587-1597.

25. Livak KJ \& Schmittgen TD (2001) Analysis of relative gene expression data using real-time quantitative PCR and the 2- $\Delta \Delta$ CT method. Methods 25, 402-408.

26. Chow S-C, Wang H \& Shao J (2007) Sample Size Calculations in Clinical Research, 2nd ed. Boca Raton, FL: Chapman \& Hall/CRC Press.

27. Murer H \& Burckhardt G (1983) Membrane transport of anions across epithelia of mammalian small intestine and kidney proximal tubule. Rev Physiol Biochem Pharmacol 96, 1-51.
28. Kavanaugh MP \& Kabat D (1996) Identification and characterization of a widely expressed phosphate transporter/ retrovirus receptor family. Kidney Int 49, 959-963.

29. Kavanaugh MP, Miller DG, Zhang W, et al. (1994) Cell-surface receptors for gibbon ape leukemia virus and amphotropic murine retrovirus are inducible sodium-dependent phosphate symporters. Proc Natl Acad Sci U S A 91, 7071-7075.

30. Custer M, Spindler B, Verrey F, et al. (1997) Identification of a new gene product (diphor-1) regulated by dietary phosphate. Am J Physiol Renal Physiol 273, F801-F806.

31. Tatsumi S, Segawa H, Morita K, et al. (1998) Molecular cloning and hormonal regulation of PiT-1, a sodium-dependent phosphate cotransporter from rat parathyroid glands 1. Endocrinol 139, 1692-1699.

32. Boyer CJ, Baines AD, Beaulieu É, et al. (1998) Immunodetection of a type III sodium-dependent phosphate cotransporter in tissues and OK cells. Biochim Biophys 1368, 73-83.

33. Kaneko I, Segawa H, Furutani J, et al. (2011) Hypophosphatemia in vitamin $\mathrm{D}$ receptor null mice: effect of rescue diet on the developmental changes in renal $\mathrm{Na}^{+}$-dependent phosphate cotransporters. Pflugers Arch 461, 77-90.

34. Stauber A, Radanovic T, Stange G, et al. (2005) Regulation of intestinal phosphate transport. II. Metabolic acidosis stimulates $\mathrm{Na}(+)$-dependent phosphate absorption and expression of the $\mathrm{Na}(+)-\mathrm{P}(\mathrm{i})$ cotransporter NaPi-IIb in small intestine. $\mathrm{Am}$ J Physiol Gastrointest Liver Physiol 288, G501-G506.

35. Huber K, Hempel R \& Rodehutscord M (2006) Adaptation of epithelial sodium-dependent phosphate transport in jejunum and kidney of hens to variations in dietary phosphorus intake. Poult Sci 85, 1980-1986.

36. Berner W, Kinne R \& Murer H (1976) Phosphate transport into brush-border membrane vesicles isolated from rat small intestine. Biochem J 160, 467-474.

37. Xu H, Bai L, Collins JF, et al. (2002) Age-dependent regulation of rat intestinal type IIb sodium-phosphate cotransporter by 1,25 $(\mathrm{OH})(2)$ vitamin D(3). Am J Physiol Cell Physiol 282, C487-C493.

38. Yan F \& Waldroup P (2006) Nonphytate phosphorus requirement and phosphorus excretion of broiler chicks fed diets composed of normal or high available phosphate corn as influenced by phytase supplementation and vitamin D source. Int J Poult Sci 5, 219-228.

39. Han JC, Yang XD, Zhang T, et al. (2009) Effects of 1alphahydroxycholecalciferol on growth performance, parameters of tibia and plasma, meat quality, and type IIb sodium phosphate cotransporter gene expression of one- to twenty-one-day-old broilers. Poult Sci 88, 323-329.

40. Saddoris KL, Fleet JC \& Radcliffe JS (2010) Sodium-dependent phosphate uptake in the jejunum is post-transcriptionally regulated in pigs fed a low-phosphorus diet and is independent of dietary calcium concentration. J Nutr 140, 731-736.

41. Huber K, Walter C, Schröder B, et al. (2002) Phosphate transport in the duodenum and jejunum of goats and its adaptation by dietary phosphate and calcium. Am J Physiol Regul Integr Comp Physiol 283, R296-R302.

42. Hattenhauer O, Traebert M, Murer H, et al. (1999) Regulation of small intestinal Na-P(i) type IIb cotransporter by dietary phosphate intake. Am J Physiol 277, G756-G762.

43. Forster IC, Hernando N, Biber J, et al. (2013) Phosphate transporters of the SLC20 and SLC34 families. Mol Aspects Med 34, 386-395.

44. Keshavarz K (1986) The effect of dietary levels of calcium and phosphorus on performance and retention of these nutrients by laying hens. Poult Sci 65, 114-121.

45. Rao SR, Reddy VR \& Reddy VR (1999) Non-phytin phosphorus requirements of commercial broilers and White Leghorn layers. Anim Feed Sci Technol 80, 1-10. 